\title{
All APPROACH TO IMPROVING PATTERNS OF POSTURE AND MOVEMENT ${ }^{\dagger}$
}

\author{
H. P. MAREE, B.Sc. Physio.) (Witwatersrand), C.T.P. (Cape Town) Dip. Phys. Ed.*
}

\begin{abstract}
Daar is verskeie oorsake van rugpyn, maar meganiese Daar van pyn. Die heropleiding van 'n posturale "patroon" van pyrid bespreek, asook oefeninge om die patroon neer worh Dis van uiterste belang dat dié pasiënt bewus te le. Dan sy bewegings- en ruspatrone en dit aanvaar wor' permanente toestand eerder as 'n spesifieke as 'n perming. So 'n patroon moet oorgedra word in daaglikse osfening. So 'n kinetiese hantering behoort deel van die korrektiewe opleiding te wees.
\end{abstract}

\section{INTRODUCTION}

At the recent refresher course for General Practitioners, held at the University of Cape Town, exercises for patients with back pain were mentioned. This for paticle has been written at the request of several of the practitioners.

The causes of "Back Pain" are varied, but where the cause is mechanical the redistribution of the body weight and thus re-alignment of the body will, in many cases, lead to relief of pain. In the post-operative situation the same principles apply in order to prevent further trauma and discomfort.

Most people have a well established "postural pattern" and the constant effort required to establish a new pattern may be considered too great if the rewards are not immediately apparent. Therefore teaching the patient how to do this is most important. The requirements must be well understood in theory, and well executed in practice. The patient must understand that his improved postural state is not "an exercise", but a "way of living". He must constantly practise what he has learned during exercise therapy.

Exercises will increase muscle power and thus make redistribution of weight and re-alignment of body structures easier to achieve. They will also, if performed with care, help the patient to become aware of his posture. However, exercises of themselves will not automatically provide better patterns of posture at rest or during movement.

\section{POSTURE CORRECTION}

The muscles acting over the joints should maintain a good alignment of the body in functional positions and activities with the minimum effort. This situation may be affected by both physical and/or emotional factors. If there is a structural imbalance the patient must learn to compensate, and to become, as far as possible, a bilaterally symmetrical human being. The common factor for each person is to become aware of his body image and to experience an improved position of his body in space; to be able to recognise when his body alignment is not ideal, and to be able to correct it Body build is an important consideration, but improved weight distribution will always lead to improved appearance and a feeling of well-being.

The concept of the ideal standing posture, in which

* Lecturer, University of Cape Town.

$\dagger$ Adapted from a paper read at a Refresher course for General Practitioners, held at University of Cape Town. a plumbline passes through various points of the body and falls at a point in the centre of the base is well known (Fig. 1).

To test for the distribution of the body weight over the base watch the patient rise up onto his toes. If he has to swing his body weight forward before rising, then his weight is too far back. When the weight is centred over the fore part of the feet the patient will rise directly up onto his toes.

Should the body be correctly aligned, but the weight over the heels, the patient will fall backwards (Fig. 2). In order to prevent this he pushes his hips forward and leans back at the waist, thus tilting his pelvis well forward. He then pokes his head forward, and his shoulders droop. Usually his knees are pressed into hyperextension, thus accentuating the position (Fig. 3). This is the situation which frequently predisposes to backache

In order to correct his posture the patient should

(i) Grow tall from the crown of his head;

(ii) "Unlock" his knees and hold them in a neutral position;

(iii) Grow tall;

(iv) Transfer his weight over the fore part of his feet;

(v) Grow tall;

(vi) Lean slightly forward at the waist - should this be necessary.

There is no need to pull the shoulders back; if the posture is adjusted as suggested the shoulders will automatically hang into place. There is very little muscular effort involved, but a great deal of "awareness" of good postural alignment. The method, slightly modified, can be applied when sitting and walking, but here the grow tall element is the most important.

Whether poor posture is responsible for backache or vice versa, it is true that improved posture alleviates backache if it does not dispose of it altogether. Thus, even if a cure is not effected, persistent correction of body alignment may well prevent the backache from worsening.

\section{EXERCISE THERAPY}

The final aim of treatment is to make the patient aware of his body "pattern" at all times, therefore the exercises must be taught carefully and accurately, with rhythmic, repetitive movements and avoiding jerking. The way in which the exercises are performed is more important than the movement itself. One or two exercises well done will be more beneficial than many badly done. The exercises chosen must not be too difficult for the patient for this will result in a poor, ineffective performance. An important concept is that of TRUNK exercises rather than abdominal or back exercises. All muscles acting on the trunk should be used in a balanced way as should control over the areas of the back, i.e. cervical, dorsal and lumbar areas in order to prevent excessive contrast between anterior and posterior curves.

One stringently applied rule is that of avoiding hyperextension because this is a position of undue strain. An imbalance of muscle power where the back muscles are much stronger than the abdominals is a common situation which may too easily be exaggerated. This is not critical with, for example, gymnasts or ballet 


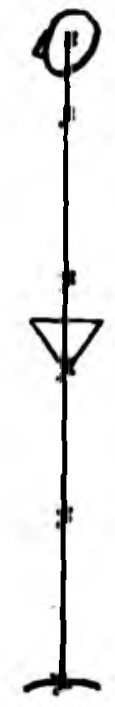

Fig 1

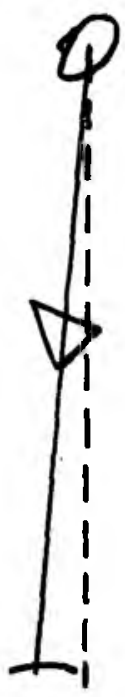

Fig. 2

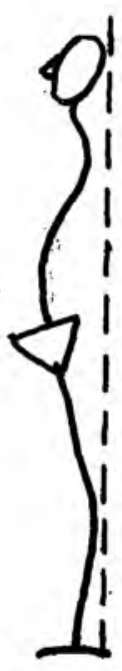

Fig. 3

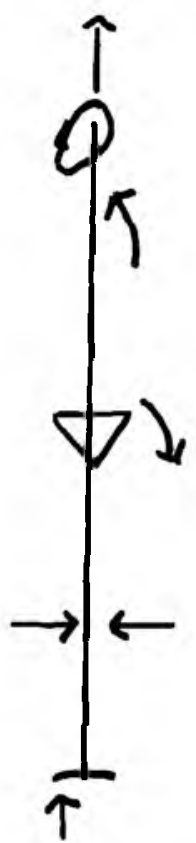

Fig. 4 dancers who do have good muscle power, an acute awareness of body position, and the ability to control it.

Any movement is dependent upon the stable background supplied by another part of the body which, in turn, affects the quality of the movement. In teaching trunk control we must consider flexion and extension; side flexion; rotation, as well as all movements of the pelvis viz. anterior and posterior tilt; lateral tilt; rotation.

Correct breathing emphasizes control of the trunk muscles, particularly those of the abdominal corset, the rule being to breathe out on effort. When doing an exercise that involves contracting the long muscles of the back as the phase of maximum effort, the patient breathes out at the same time which causes a strong contraction of the abdominal muscles. This results in hyperextension being prevented while the trunk muscles co-contract in a balanced manner, thus giving stability to the trunk in a position of good alignment. Of course, the patient must become aware of this position.

When the abdominal muscles are working in an exercise such as sit-ups, or variations thereof, the pelvis must be tilted backwards before beginning the exercise. This will cause tension to be generated and the slack to be taken up in the abdominal muscles, thus during the exercise the pelvis will be retained in that position and jerking into hyperextension will be avoided. Usually, if a muscle is stretched when in a state of tension, the contraction that follows will be a strong one. In practice the abdominals do not comply with this rule. When the back is hyperextended and the abdominals are being stretched, an attempt to contract them will not bring about a strong effective contraction, but if the pelvis is tilted backwards and the hyperextension eliminated, the abdominals will contract much more efficiently.

Before choosing suitable exercises for the patient his physical ability must be assessed and note taken of any limitations such as tight hamstrings or Achilles tendons. No corrective exercises should be done without prior warming up activities. Swinging exercises are most effective for this purpose. In general untrained persons do not enjoy running or jumping as an introductory activity and no purpose is served by insisting on starting this way.

The most useful corrective exercises are those which teach trunk control and make the patient aware of an improved body image, and the position of his body in space, so that the benefits may be carried over into his every day activities. A position in which the body is more fully supported, e.g. supine, will aid a good isometric starting position, and the isotonic work required for the exercise need not be easy, whereas a starting position in which the body is less fully supported, e.g. standing, may require greater awareness and control of the isometric work in order to maintain that position, while the isotonic work of the exercise may be relatively easy.

The essential feature of all corrective exercises for posture is that of "stretch" and "awareness"; therefore the patient must concentrate, work accurately and repeat the movements in order to groove a habit. 
WARM UTP: Anti-gravity Swing

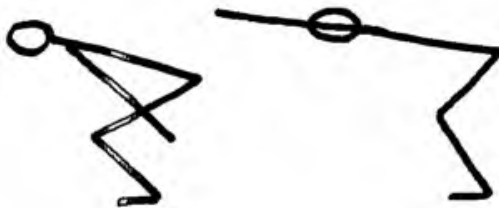

SUPINE:

(i) Pelvic tilt

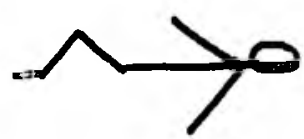

Fig. 6

1. Press knees and thighs altogether.

2. Tighten buttocks.

3. Pull stomach in.

4. Slowly relax.

Breathe out with steps $1,2,3$.

Breathe in with step 4.

To make the exercise more difficult

the legs may be progressively straightened.

\section{PRONE KNEELING}
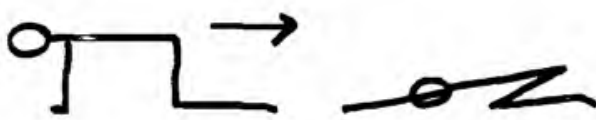

1. Sit back on the heels.

Fig. 5

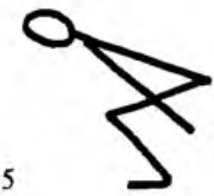

(ii) Trunk curl

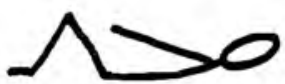

Fig. 7

1. Lift the head and shoulders and reach towards the knees.

2. Lie back and relax.

The thighs should be pressed together, and the feet pressed onto the floor to supply a stable background posture.

Breathe out with step 1.

Breathe in with step 2 .

These two exercises should be performed in a controlled rhythmical way.
1. Swing arms back. Bend and semi-stretch knees "bounce".

2. Swing arms forward to horizontal bend and semi-stretch knees.

3. Repeat 1.

4. Swing up to stand tall and "stretch". Do not lean backwards.

\section{PRONE:}

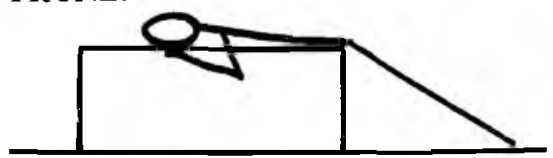

Fig. 8

Graceline

Lie relaxed with arms resting on table or holding sides of the table. The hip joint at edge of table. This position may need to be adjusted to allow for the patient's body build and balance

1. Press legs together and stretch. Lift legs up a few cms.

2. Hold for $2-3$ counts.

3. Lower to floor.

4. Relax and pause.

Breathe out with steps 1, 2, 3 .

Breathe in with step 4.

3. Push forward until nose is level with, or past,

Catlap the fingers.

\section{LONG SITTING OR HIGH SITTING}

If the patient has short hamstrings the exercise may be done in high sitting, but will not be quite as fffective.

\section{Hitching and Hiking}

The shoulders should be held square, and the trunk should be displaced as little as possible.

1., Transfer weight onto left buttock.

2. Shorten right side flexors and lift right buttock and leg from floor.

3. Push right foot forward past left foot.

4. Allow right leg and buttock to return to floor.

Repeat with opposite side.

This exercise brings in rotation of the trunk with complete safety.

\section{STANDING}

\section{Squats}

This exercise must be done slowly with good control. The shoulders should be above the hips, which should be above the heels throughout the exercise. This is necessary in order to teach correct kinetic handling and thus protection of the back.

\section{POSTURE CORRECTION}

This should be watched and corrected at all times. A mirror is useful so that the patient may watch himself.

There are several teaching artefacts which one may use in order to educate the patient's awareness and sensation of what he is required to achieve, but these cannot be used as the end in itself because in the every-
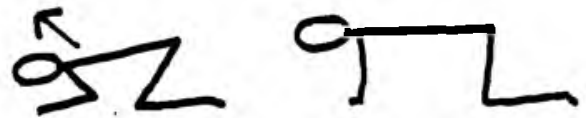

Fig. 9

4. Push up to regain starting position.

The abdominal muscles must be held contracted constantly in order to prevent the back sagging.

Breathe out during phases 2-4.

day situation the patient must use minimum effort to reach a permanent end result.

Example: In sitting: pulling in the stomach and taking a deep breath will cause the pelvis to tilt backwards and the patient will momentarily experience the required position. Functionally however, we breathe out as we tilt the pelvis and maintain the position while we continue to breathe.

Example: Over-correction of a position or movement is again designed to aid the patient's experience of his body position. In practice we seldom do the correct movement until we have experienced the extremes of "correct" and "incorrect".

Hanging from a beam is often suggested as a means of helping to realign the body but, unless the patient has very strong upper limb and shoulder girdle, he will be struggling to hold on and will be quite unable to relax his trunk muscles, thus achieving nothing. Correcting the body alignment in supine, and resting in that position, will give a more beneficial result.

\section{CONCLUSION}

It is clear that teaching the patient is the most important factor in helping him to become aware of his movement and resting patterns and that the concept of this as a constant state rather than an exercise is of equal importance. Carry over into everyday activities should be emphasized and kinetic handling should be a part of the corrective education. The time spent in helping the patient to "groove" good habits is not wasted when the end results can be so beneficial. 


\section{BARFORD JONES}

SURGICAL SUPPLY Co. (Pty) Ltd.

Nedbank East City, Endstraat 120,

Johannesburg 2001.

Telefone: $22-5238 \& 22-5363 / 4$

Telegramme: Posbus 5484, Johannesburg 2000

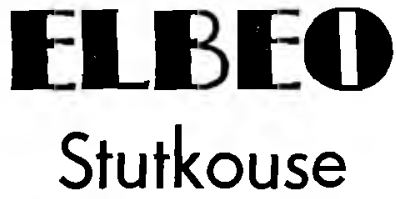

ELBEO STUTKOUSE word hoofsaaklik bedoel vir gevalle van spatare en is ook ideaal vir verligting van moeë pynlike bene en vir gevalle waar bene pyn, klop of swel

Naatloos vir nuwerwetse mode en deursigtig genoeg vir alledaagse drag, met sandale-hak en versterkte naatpunt. Deursigtige broekie met leerweerstandige omgebreide hak om 'n perfekte pas en lange diens te verseker.

Beskikbaar in drie groottes: Groot, Middelgroot en Klein asook in ses modewetse skakerings.

\section{A. C. Miller \& CO.} ORTHOPAEDIC MECHANICIANS

Technicians registered with S.A. Medical and Dental Council specialising in the following: ORTHOPAEDIC APPLIANCES, SURGICAL CORSETS, CERVICAL COLLARS, CHILDREN'S SHOES AND BOOTS, ARTIFICIAL LIMBS,

LATEST IN PLASTIC MODIFICATION. HIRING AND SELLING OF HOSPITAL EQUIP. MENT AND SICK ROOM REQUISITES, e.g. WHEEL CHAIRS, COMMODES, HOSPITAL BEDS, WALKING AIDS, TRACTION APPARATUS, etc.
Telephone 23-2496
P.O. Box 3412 275 Bree Street

\section{THE SOUTH AFRICAN SOCIETY OF PHYSIOTHERAPY}

\section{President}

MR. JAMES J. CRAIG

Vice-Presidents

PROFESSOR T. L. SARKIN

PROFESSOR L. SOLOMON

DR. L. VAN DER MERWE

PROFESSOR J. P. VAN VUREN

PROFESSOR F. ZIADY

Honorary Life President

PROFESSOR B. BROMILOW-DOWNING

\section{Honorary Life Vice-Presidents MISS LOIS DYER MISS JEAN BLAIR MR. A. ROTHBERG}

\section{Chairman}

MRS. K. M. LEVY

Immediate Past-Chairman

MISS MARGARET EMSLIE

Vice-Chairmen

MRS. A. MATHIAS

MISS E. M. BOTTING

General Secretary: All correspondence to P.O. Box 11151, Johannesburg 2000.

General Treasurer: MISS N. H. BAINES.

Journal Editor: Mrs. N. GILDER, 8 Clee Road, Observatory, Cape 7925.

Minute Secretary: MRS. J. WELLS.

National Executive Committee: Miss P. Bowerbank, Mrs. F. Glauber, Mrs. N. Lennard, Mrs. A McFarlane, Miss L. Pretorius, Mrs, S. Keays.

Appointments Information Secretary: Miss Priscilla Blake, South African Society of Physiotherapy, P.O. Box 11151, Johannesburg.

\section{BRANCH SECRETARIES}

Border (East London): Mrs. P. R. Morar, P.O. Bo 1419, East London 5201.

Eastem Province (Port Elizabeth): Miss H. Smith, 1404 Oasim North, Havelock Street, Port Elizabeth 6001.

Goldfields (Welkom): Miss R. Germishuys, P.O. Box 1515, Welkom 9460.

Natal Coastal (Durban): Miss M. Hudson, 116 Hillcon Towers, Umhlanga Rocks 4320.

Natal Midlands (Pietermaritzburg): Mrs. A. Londt, 54 Moss Place, Montrose, Pietermaritzburg 3201.

Northern Cape (Kimberley): Mrs. P. L. Farrer, 4 Rouse Road, West End, Kimberley 8301.

Northern Transvaal (Pretoria): Miss Y. van der Mast, P.O. Box 27804, Sunnyside, Pretoria 0132.

S.O.F.S. (Bloemfontein): Mej. A. B. Pretorius, p/a Martie du Plessisskool, Du Plooysingel 91, Pk. Drusana, Bloemfontein 9301.

Southern Transvaal (Johannesburg): Mrs. S. Cadman, P.O. Box 775, Rivonia, Johannesburg 2128.

Western Province (Cape Town): Miss M. S. Uys, Department of Physiotherapy, P.O. Box 63, Tygerberg - Cape 7505. 